\title{
Narratives of endurance and the ethics of listening
}

\author{
GAYATHRI PRABHU
}

\begin{abstract}
This is a commentary on the ethics of listening as can be gleaned from two narratives drawn from real-life encounters and crafted in the mode of fiction. "The Spiral" by Rakhi Ghoshal and "The Liquid Miscreant" by Aiswarya Sasi are narratives of the indignities inflicted by alcoholism on families and individuals. The narrators in both instances are outsiders who have to listen and bear witness to the suffering and resistance that they witness. This commentary argues that both narratives offer readers an opportunity to reflect on what is entailed in the ethics of listening. It is hence suggested that the components of an active, dynamic and ethical listening entail empathetic presence, non-intrusive reception, and bearing witness with compassion.
\end{abstract}

Keywords: Ethics of listening, alcoholism, health humanities, narrative of substance abuse

This is a tale of two narratives, both included below. "The Spiral" by Rakhi Ghoshal (1) and "The Liquid Miscreant" by Aiswarya Sasi (2) have been drawn from real-life encounters and encapsulated by the tools of fiction. Characters, scenes and situations come alive in these narratives through plot, dialogue, descriptions, imagery and reflection. An advocacy spirit fuels both narratives-a keen awareness of the indignities that alcoholism inflicts upon any family. Invariably, these become narratives of suffering and resistance that are told to (or perhaps received by) two outsiders who have to listen, bear witness, reflect, recollect, narrate-the narrator of "The Spiral" hears the story at the crisis intervention centre of a public hospital in Mumbai; the narrator of "The Liquid Miscreant" is a second-year medical student with a clinical posting in the psychiatry department. In both situations, there is not much the listener can do by way of intervention, for they stand on the other side of the fierce fences of privacy and (dis)loyalty of the family unit, and the response thus gets located in the act of listening itself.

Author: Gayathri Prabhu (gayathri.prabhu@manipal.edu), Associate Professor, Manipal Centre for Humanities, Manipal, Karnataka, INDIA.

To cite: Prabhu G. Narratives of endurance and the ethics of listening. Indian J Med Ethics. 2021 Oct-Dec; 6(4) NS: 332-33. DOI: 10.20529/IJME. 2021.034.

Published online on May 1, 2021.

c) Indian Journal of Medical Ethics 2021
There is no getting around the fact that any professional working in the health industry is constantly receiving, processing and responding to life narratives. Indeed, listening is an integral part of the diagnostic, therapeutic and curative processes. And sometimes, as with the two narratives being discussed, the space and act of listening becomes charged: the listener feels the full affective impact of the distress of the people they are listening to, and this becomes especially complicated when children are entangled in the complex manifestations of violence and abandonment. What is being shared is disturbing to the listener and by extension to us, the readers, but it is not a disturbance that we want to walk away from. No, we understand that we must listen, and that the listening must also be reflexive and responsible. Rita Charon and Martha Montello in their Introduction to Stories Matter: The Role of Narrative in Medical Ethics (3) emphasise that "narrative approaches to ethics recognise that the singular case emerges only in the act of narrating it and that duties are incurred in the act of hearing it" (3). What are the contours of these duties? Is there an ethics to listening and what does this ethics entail?

In "The Spiral" we listen to "the slaps and the punches, the accusations and the abuses" of an alcoholic husband and the "fossilised anger" of the wife that vents out on their four-yearold child. In "The Liquid Miscreant' we listen to a nine-year-old boy whose "demeanour transformed" from happy chatter to silent frown at the arrival of his mother, and then the familiar spill-over of violence: "after my father comes home and beats her, she becomes sad and she cries and if I ask her anything, she beats me." As the author of "The Spiral" reminds us in a note, there are legal protections against domestic violence, and this is true of some forms of child abuse as well (although many kinds of abusive behaviour towards children get social validation in the name of disciplining and parenting), but that does not address every situation or varied dimensions of specific situations. What these two authors thus seek to do from their listening and observation is to shape a narrative. Could it be that a thoughtfully crafted narrative, that is attentive to its voice and perspective, is the first step towards ethical listening?

Arthur Kleinman, whose The Illness Narratives (Basic Books, 1988) has become a keystone text for the study of Medical Humanities, recently published a memoir called The Soul of Care with the subtitle "the moral education of a husband and 
a doctor" Anchored in the experience of taking care of his ill and dying wife, and looking back over the journey that brought him to a certain mode of practising medicine, Kleinman attributes the shaping of this "moral education", fairly early in the book, to an ability to listen:"I learned to be an intense listener, a sharp observer of people's struggles to make sense of their worlds and themselves [...] As I listened and people talked, I learned to hear not only their words but also their human tone" (4). This differentiation that Kleinman makes between the listening self and the speaking other, between "their words" and "their human tone", is significant to the nuances of how language is received. Words offer us content and meaning, but perhaps the ethics of listening is in the other category that Kleinman calls the human tone-not only what happened but how that feels or what that implies. Around any text (what is being said) we also find its context (a larger orb of the socio-economic, cultural, political factors) and its subtext (all that remains implied, subtle, unsaid) - a reflexive and ethical listener trains to pay attention to as many of these variables as possible. To be fully present with all of one's faculties, to absorb the telling without offering platitudes or inserting oneself too quickly into someone else's story, and to find ways to bear witness with compassion are components of an active, dynamic and ethical listening.

Here then we have two texts that provide examples of bearing witness, of listening that finds a way to writing. For those of us who are invested in the possibility of narrative as a tool for learning and change, these writings offer pedagogical material for discussion on ethics in classrooms and clinical spaces. From listening and writing, to teaching and learning, "The Spiral" and "The Liquid Miscreant" hence become narratives of endurance that renew our ethical imperatives. It is now for us to read, reflect and respond. Reading is listening too.

\section{References}

1. Ghoshal R. The Spiral. Indian J Med Ethics. Published online first on May 1,2021.DOI:10.20529/JME.2021.031.

2. Sasi A. The Liquid Miscreant. Indian J Med Ethics. Published online first on May 1, 2021.DOI: 10.20529/JMME.2021.032.

3. Charon R, Montello M. Stories matter: The role of narrative in medical ethics. New York: Routledge; 2002. 1st ed. 254 pgs.

4. Kleinman A. The soul of care: the moral education of a husband and a doctor. Great Britain: Penguin Random House; 2020.p 17. 